\title{
Hedgehog signalling is downregulated in celiac disease
}

\author{
Rui Liang PhD ${ }^{1,2,3}$, Rupert Hinds $\mathrm{MD}^{4,5}$, Helen E Abud $\mathrm{PhD}^{6}$, Wei Cheng PhD ${ }^{1,2,3,4,7}$
}

\begin{abstract}
R Liang, R Hinds, HE Abud, W Cheng. Hedgehog signalling is downregulated in celiac disease. Can J Gastroenterol 2013;27(1): e5-e8.
\end{abstract}

BACKGROUND: Celiac disease (CD) is a common autoimmune disorder of the small intestine that occurs in genetically predisposed individuals. Animal studies have suggested that the hedgehog ( $\mathrm{Hh})$ signalling pathway is involved in gut inflammation, injury and repair. OBJECTIVE: To examine the expression of components of the $\mathrm{Hh}$ signalling pathway in CD.

METHODS: Children undergoing gastroscopy investigation for $\mathrm{CD}$ at Monash University (Victoria, Australia), and other children undergoing gastroscopy in whom small bowel pathology was not expected (ie, controls), were included in the present study. One histopathologist, who was blinded to the biopsy data, analyzed the biopsies and a diagnosis of $\mathrm{CD}$ was made according to standard Marsh criteria. From these samples, RNA was extracted and complementary DNA was synthesized using reverse transcription polymerase chain reaction. The levels of Hh ligand Sonic hh, Indian hh, protein patched homologue 1 (PTCH 1) and bone morphogenetic protein 4 (BMP4) messenger RNA were quantified by real-time polymerase chain reaction. Relative expression quantification was performed using the $\Delta \Delta \mathrm{Ct}$ method. RESULTS: Duodenal biopsies were collected from 37 children. There were $20 \mathrm{CD}$ specimens and 17 normal controls. The relative expression of Sonic hh from CD patients was $58 \%$ lower than that of the controls; similarly, Indian hh expression was decreased in children with CD by $44 \%$. Compared with controls, the expression of $\mathrm{Hh}$ receptor PTCH 1 decreased by $71 \%$ and the expression of the $\mathrm{Hh}$ target gene BMP4 by $42 \%$.

CONCLUSIONS: The expression of the Hh signalling pathway genes was consistently downregulated in untreated CD children. These results suggest that the $\mathrm{Hh}$ signalling pathway plays a role in the mucosal lesions encountered in CD.

Key Words: BMP4; Celiac disease; Duodenum; Hedgehog signalling; PTCH1

Celiac disease (CD) is a common autoimmune disorder of the small intestine that affects genetically predisposed individuals of all ages. The prevalence is $1 \%$ in Western populations. This disease is caused by an immune-mediated response to dietary gluten. The response leads to an enteropathy characterized by villous atrophy, crypt hyperplasia and increased numbers of intra-epithelial lymphocytes. Treatment consists of lifelong dietary gluten exclusion with resolution of the lesion(s) the expectation.

The hedgehog $(\mathrm{Hh})$ signalling pathway is known to be essential in gastrointestinal patterning and development. Hh signalling stimulates mesenchymal growth in the developing digestive tract (1). This signalling is vital to the patterning of the intestinal crypt-villus axis in mice (2). In mice with Hh signalling pathway gene mutations, gastrointestinal anomalies, including duodenal stenosis, aganglionic colon, imperforate anus and anorectal malformation, have been observed (3-5).

\section{Une régulation négative du signal Hedgehog en cas de maladie coliaque}

HISTORIQUE : La maladie cœliaque (MC) est un trouble auto-immun courant de l'intestin grêle qui se déclare chez des personnes prédisposées sur le plan génétique. Les études chez des animaux laissent croire que la voie de signalisation Hedgehog $(\mathrm{Hh})$ participe à l'inflammation, aux lésions et à la réparation de l'intestin.

OBJECTIF : Examiner l'expression des éléments de la voie Hh en cas de MC.

MÉTHODOLOGIE : Les chercheurs ont inclus dans la présente étude des enfants ayant subi une gastroscopie en raison d'une $\mathrm{MC}$ à l'université Monash de Victoria, en Australie, ainsi que d'autres enfants ayant subi une gastroscopie, mais chez qui on ne prévoyait pas la présence d'une pathologie du grêle (sujets témoins). Un histopathologiste, qui n'était pas informé des données de biopsie, a analysé les biopsies et posé un diagnostic de MC conformément aux critères de Marsh standards. À partir de ces échantillons, les chercheurs ont extrait l'ARN et synthétisé l'ADN complémentaire au moyen de la réaction en chaîne de la polymérase par transcription inverse. Les chercheurs ont quantifié le taux d'ARN messager dans les ligands Hhde la protéine Sonic hh, la protéine Indian hh, la protéine homologue patched 1 (PTCH 1) et la protéine morphogénétique osseuse 4 (BMP4) par réaction en chaîne de la polymérase en temps réel. Ils ont quantifié l'expression relative au moyen de la méthode $\Delta \Delta \mathrm{Ct}$.

RÉSULTATS : Les chercheurs ont prélevé des biopsies duodénales chez 37 enfants. Ils comptaient 20 échantillons de MC et de 17 sujets témoins. L'expression relative de la protéine Sonichhchez les patients ayant la MC était $58 \%$ plus faible que celle des sujets témoins. De même, l'expression de la protéine Indian hh était $44 \%$ plus faible chez les enfants ayant la MC. Par rapport aux sujets témoins, l'expression du récepteur PTCH 1 diminuait de $71 \%$ et celle du gène cible BMP4 Hh, de $42 \%$.

CONCLUSIONS : Chez les enfants ayant une MC non traitée, on observait une régulation négative constante de l'expression de la voie Hh. D'après ces résultats, la voie Hh participe aux lésions muqueuses observées en cas de MC.

In the mature gut, $\mathrm{Hh}$ is localized to the region of the crypts where intestinal stem cells reside and it is suspected that Hh plays a role in stem cell regulation and, thus, it may also be involved in epithelial proliferation (6). Hh signalling is also involved in the injury-induced repair of the bladder that originates from the hindgut during embryogenesis (7). Indian $\mathrm{Hh}$ (Ihh) regulates intestinal stem cell self-renewal and differentiation through epithelial-mesenchymal interactions during development (8). Abnormal regulation of the Hh signalling pathway has been linked to many human cancers, including gastrointestinal cancers, highlighting its role in promoting proliferation $(9,10)$. Hh signalling is linked to repair of tissues such as skeletal muscle (11), bones (12), myocardium (13) and skin (14). The aim of the present study was to assess the expression of $\mathrm{Hh}$ signalling molecules in the enteropathy associated with CD before starting a gluten-free diet when compared with controls.

${ }^{1}$ Key Laboratory of Developmental Diseases in Childhood (Chongqing Medical University), Ministry of Education, China; ${ }^{2}$ Department of Paediatric

Surgery, Monash Medical Centre, Southern Health; ${ }^{3}$ Monash Institute of Medical Research, ${ }^{4}$ Department of Paediatrics; ${ }^{5}$ Department of Paediatric

Gastroenterology, Southern Medical School, Faculty of Medicine, Nursing and Health Sciences; ${ }^{6}$ Department of Anatomy and Developmental Biology,

${ }^{7}$ Department of Surgery, Monash University, Victoria, Australia

Correspondence: Dr Rupert Hinds, Department of Paediatrics, Monash Medical Centre, 246 Clayton Road, Clayton, Victoria 3168, Australia.

Telephone 61-3-95946666, fax 61-3-95943697, e-mail rupert.hinds@southernhealth.org.au

Received for publication March 14, 2012. Accepted August 12, 2012 


\section{TABLE 1}

Expression levels of hedgehog signalling pathway genes in celiac disease (CD) and normal controls

\begin{tabular}{lcclc}
\hline & \multicolumn{1}{c}{$\boldsymbol{S h} \boldsymbol{h}$} & \multicolumn{1}{c}{$\boldsymbol{I h \boldsymbol { h }}$} & \multicolumn{1}{c}{$\boldsymbol{P T C H 1}$} & \multicolumn{1}{c}{$\boldsymbol{B M P 4}$} \\
\hline $\mathrm{CD}(\mathrm{n}=20)$ & $0.52 \pm 0.074^{*}$ & $0.48 \pm 0.055^{* *}$ & $0.24 \pm 0.036^{* *}$ & $0.57 \pm 0.053^{* *}$ \\
Control $(\mathrm{n}=17)$ & $0.89 \pm 0.082$ & $0.85 \pm 0.052$ & $0.84 \pm 0.14$ & $0.99 \pm 0.071$ \\
\hline
\end{tabular}

Data presented as mean \pm SE. ${ }^{*} P<0.005 ;{ }^{* *} P<0.0001$. BMP4 Bone morphogenetic protein 4; Ihh Indian hedgehog; Shh Sonic hedghog; $\mathrm{PTCH} 1$ Protein patched homologue 1

\section{METHODS}

Subjects and histological diagnosis

The present study was approved by the institutional human research ethics committee. Children undergoing gastroduodenoscopy for investigation of possible $\mathrm{CD}$, including children with both symptoms and/ or serology consistent with the diagnosis as well as those who had been screened because of a high risk for CD, such as children with type I diabetes and found to have positive serology, were recruited for the study. Included as controls were age-matched children in whom CD or other small bowel pathology was not expected to be diagnosed. Informed written consent or assent was obtained as appropriate. Biopsies were taken and analyzed blindly by a pathologist; a diagnosis of $\mathrm{CD}$ was made according to the standard Marsh criteria. Additional duodenal biopsies were also taken from these children and stored; transported in RNAlater (Ambion, USA) and maintained at $-80^{\circ} \mathrm{C}$ for later use.

RNA isolation and quality controls

Total RNA was extracted from tissue using a commercially available kit (RNeasy Mini Kit, Qiagen, USA). Homogenization was performed using $1.4 \mathrm{~mm}$ ceramic beads (Mobio, USA) in lysis buffer. Samples were shaken using a homogenizer (Precellys 24 Lysis and Homogenization machine, Precellys, USA). Optional DNase digestion was also performed. The concentration and quality of the isolated RNA were measured spectrophotometrically (Nanodrop, Thermo Fisher Scientific Inc, USA). The total RNA $(<3 \mu \mathrm{g})$ was primed with oligo(dT)20 (Invitrogen, USA) and reverse transcribed to complementary DNA using Moloney murine leukemia virus reverse transcriptase (Invitrogen) in a total volume of $20 \mu \mathrm{L}$ as per manufacturer's instructions. Control reactions were performed using control RNA (HeLa) provided by the manufacturer.

Real-time polymerase chain reaction

Real-time polymerase chain reaction (PCR) reactions were run in triplicate in 384-well plates using the Applied Biosystems 6900HT Fast RTPCR System (Applied Biosystems, USA). Blank controls were included in parallel for each primer SYBR Green master mix (Applied Biosystems, USA). Each reaction contained $5 \mu \mathrm{L}$ SYBR Green PCR master mix, $200 \mathrm{mM}$ forward and reverse primers, $1 \mu \mathrm{L}$ complementary DNA and distilled water up to a total volume of $10 \mu \mathrm{L}$.

The cycling conditions were as follows: initial template denaturation at $95^{\circ} \mathrm{C}$ for $10 \mathrm{~min}$, followed by 40 cycles of denaturation at $95^{\circ} \mathrm{C}$ for $15 \mathrm{~s}$, annealing and elongation at $58^{\circ} \mathrm{C}$ for $1 \mathrm{~min}$. These cycles were followed by melt-curve analysis: $95^{\circ} \mathrm{C}$ for $15 \mathrm{~s}, 58^{\circ} \mathrm{C}$ for $15 \mathrm{~s}$ followed by $95^{\circ} \mathrm{C}$ for $15 \mathrm{~s}$. The relative expression quantification was determined by reference to beta-actin expression using the $\Delta \Delta \mathrm{Ct}$ method.

\section{Statistical analysis}

All data were expressed as mean \pm SE. Statistical data were collected and calculations performed using a spreadsheet (Excel, Microsoft Corporation, USA). The Student's $t$ test was applied for data analysis using GraphPad Prism software (GraphPad Software Inc, USA); $\mathrm{P}<0.05$ was considered to be statistically significant.
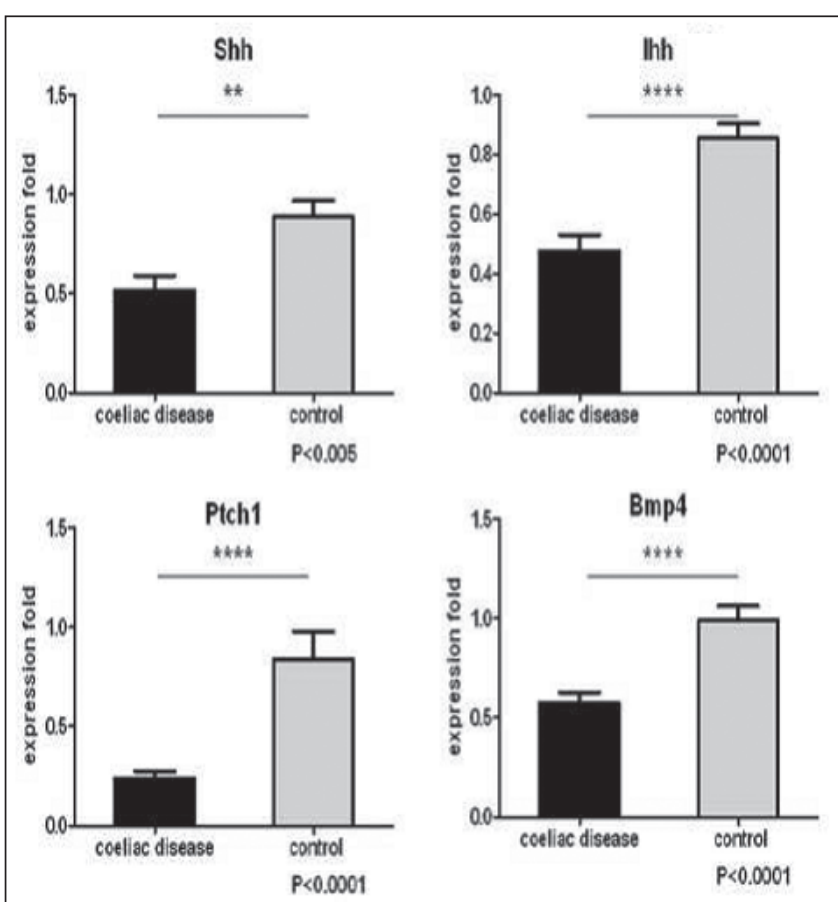

Figure 1) Expression levels of Sonic hedgehog (Shh), Indian hedgehog (Ihh), Protein patched homologue 1 (Ptch1) and bone morphogenetic protein 4 (Bmp4) in celiac disease and controls. $* * P<0.005$; $* * * P<0.001$

\section{RESULTS}

Small bowel biopsies were obtained from 37 children including 20 children (median age six years, range two to 13 years) diagnosed with CD by histology and 17 children (median age seven years, range three to 15 years) who had normal small bowel histopathology (controls). There was no statistically significant difference in age between the two groups. The results of the expression data are summarized in Table 1.

Of the three Hh ligands present in humans, Sonic Hh (Shh), Ihh and Desert Hh, only Shh and Ihh are expressed in the gut. The mean $( \pm \mathrm{SE}$ ) expression level of Shh in the CD group was found to be $58 \%$ lower $(0.52 \pm 0.074)$ than that of the control group $(0.89 \pm 0.082)$ $(\mathrm{P}<0.005)$. Similarly, the Ihh expression showed a decrease of $56 \%$ compared with that of the control group $(0.48 \pm 0.055$ versus $0.85 \pm 0.052)(\mathrm{P}<0.0001)$.

Protein patched homologue 1 (PTCH1) is not only the inhibitor membrane receptor but also one of the main target genes in the $\mathrm{Hh}$ pathway. PTCH1 expression was down-regulated by $71 \%$ in the $\mathrm{CD}$ group $(0.24 \pm 0.036$ versus $0.84 \pm 0.14)(P<0.0001)$. Bone morphogenetic protein 4 (BMP4) is one of the target genes in $\mathrm{Hh}$ signalling. BMP4 expression decreased by $42 \%(0.57 \pm 0.053)$ compared with that of the control group $(0.99 \pm 0.071)(\mathrm{P}<0.0001)$ (Figure 1).

No relationship between the degree of villous atrophy and/or Marsh score as categorized by the histopathologist, and the expression level of any of the molecules assessed was observed in the present study.

\section{DISCUSSION}

The results of the present study demonstrated for the first time that $\mathrm{Hh}$ signalling pathway ligands and downstream transcriptional targets are significantly downregulated in the duodenal epithelia of children with untreated CD. This information will further expand the understanding of intestinal repair and injury in human subjects. While larger studies will be needed to confirm these findings, we believe that the magnitude of difference makes it likely to be reproducible. Furthermore, it is not clear at this stage whether expression would be downregulated in small bowel damage outside the setting of $\mathrm{CD}$; we are planning future studies within our department to quantify $\mathrm{Hh}$ expression in other 
small bowel pathologies. This will help clarify whether the decreased expression of Ihh and Shh simply reflects a reduction in epithelial cells consequent to the villous atrophy. Our study remains, however, one of the first to investigate $\mathrm{Hh}$ signalling in small bowel pathology in human subjects.

Hh signalling has previously been linked to the repair of many tissues types, including the gut, and has been suggested to play a role in promoting proliferation in many human cancers. In a previous study by Nielsen et al (15), Hh signalling was shown to increase in response to intestinal injury. This finding is consistent with the results of a previous report (16), which showed that Hh signalling is involved in the repair of gastric ulcers. Our study suggests that in humans with CD, Hh signalling may be diminished in the setting of ongoing immunemediated damage.

Recently, Zacharias et al (17) demonstrated that chronic suppression of gut Hh signalling in transgenic mice leads to villous atrophy and wasting. In addition, microarray data revealed upregulation of many genes that are usually involved in inflammation. Similarly, in another model using transgenic mice (18), prolonged inhibition of the Hh pathway led to leukocyte infiltration of the crypt area, blunting and loss of villi, and fibrosis (18). While the relationship between $\mathrm{Hh}$ signalling and the lesions of CD is not clear, our results appear to be consistent with these findings in animal models of small bowel damage.

It remains unclear, of course, as to what role Hh downregulation plays in the pathogenesis of CD and, equally, whether it would be present in other enteropathies. Nevertheless, downregulation of $\mathrm{Hh}$ is observed in many animal models of intestinal injury. Future studies investigating other small bowel damage would be extremely useful in this context. Ideally, we would have also liked to measure levels of $\mathrm{Hh}$ expression in children after commencement of a gluten-free diet to

\section{REFERENCES}

1. Mao J, Kim BM, Rajurkar M, et al. Hedgehog signaling controls mesenchymal growth in the developing mammalian digestive tract. Development 2010;137:1721-9.

2. Madison BB, Braunstein K, Kuizon E, et al. Epithelial hedgehog signals pattern the intestinal crypt-villus axis. Development 2005;132:279-89.

3. Ramalho-Santos M, Melton DA, McMahon AP. Hedgehog signals regulate multiple aspects of gastrointestinal development. Development 2000;127:2763-72.

4. Sukegawa A, Narita T, Kameda T, et al. The concentric structure of the developing gut is regulated by Sonic hedgehog derived from endodermal epithelium. Development 2000;127:1971-80.

5. Ming JE, Roessler E, Muenke M. Human developmental disorders and the Sonic hedgehog pathway. Mol Med Today 1998;4:343-9.

6. Barker N, van Es JH, Kuipers J, et al. Identification of stem cells in small intestine and colon by marker gene Lgr 5 . Nature 2007;449:1003-7.

7. Shin K, Lee J, Guo N, et al. Hedgehog/Wnt feedback supports regenerative proliferation of epithelial stem cells in bladder. Nature 2011;472:110-4

8. Kosinski C, Stange DE, Xu C, et al. Indian hedgehog regulates intestinal stem cell fate through epithelial-mesenchymal interactions during development. Gastroenterology 2010;139:893-903.

9. Lees CW, Zacharias WJ, Tremelling M, et al. Analysis of germline GLI1 variation implicates hedgehog signalling in the regulation of intestinal inflammatory pathways. PLoS Med 2008;5:e239.

10. Beachy PA, Karhadkar SS, Berman DM. Tissue repair and stem cell renewal in carcinogenesis. Nature 2004;432:324-31. determine whether they returned to normal. However, as per European Society for Paediatric Gastroenterology, Heaptology and Nutrition (ESPGHAN) guidelines, it is no longer our practice to repeat biopsies where there has been a good clinical response with normalization of CD serology. Outside the setting of CD, our study does raise the question of whether local application of $\mathrm{Hh}$ analogues is feasible in modulating inflammation, in a similar way as local application of Shh reduced myocardial damage after infarction and accelerated wound healing in diabetic mice $(13,14)$.

\section{CONCLUSION}

Our data showed that Hh signalling appears to be downregulated in children with CD when compared with controls. While larger studies are required to confirm this finding, Hh signalling may play a prominent role in the small intestinal lesion encountered in CD.

DISCLOSURES: The authors have no financial disclosures or conflicts of interest to declare.

\section{KEY MESSAGES}

- The present study demonstrated, for the first time, that Hh signalling pathway ligands and downstream transcriptional targets are downregulated in the duodenal epithelia of children with untreated CD.

- Information from the present study will further expand the understanding of intestinal repair and injury in human subjects.

- Outside the setting of CD, it may be possible that local application of an Hh analogue could modulate gut inflammation similarly to how local application of Shh reduced myocardial damage after infarction and accelerated healing in mice.

11. Straface G, Aprahamian T, Flex A, et al. Sonic hedgehog regulates angiogenesis and myogenesis during post-natal skeletal muscle regeneration. J Cell Mol Med 2009;13:2424-35.

12. Miyaji T, Nakase T, Iwasaki M, et al. Expression and distribution of transcripts for sonic hedgehog in the early phase of fracture repair. Histochem Cell Biol 2003;119:233-7.

13. Kusano KF, Pola R, Murayama T, et al. Sonic hedgehog myocardial gene therapy: Tissue repair through transient reconstitution of embryonic signaling. Nat Med 2005;11:1197-204.

14. Asai J, Takenaka H, Kusano KF, et al. Topical sonic hedgehog gene therapy accelerates wound healing in diabetes by enhancing endothelial progenitor cell-mediated microvascular remodeling. Circulation 2006;113:2413-24.

15. Nielsen CM, Williams J, van den Brink GR, et al. Hh pathway expression in human gut tissues and in inflammatory gut diseases. Lab Invest 2004;84:1631-42.

16. Kang DH, Han ME, Song MH, et al. The role of hedgehog signaling during gastric regeneration. J Gastroenterol 2009;44:372-9.

17. Zacharias WJ, Li X, Madison BB, et al. Hedgehog is an antiinflammatory epithelial signal for the intestinal lamina propria. Gastroenterology 2010;138:2368-77;77 e1-4.

18. van Dop WA, Heijmans J, Buller NV, et al. Loss of Indian hedgehog activates multiple aspects of a wound healing response in the mouse intestine. Gastroenterology 2010;139:1665-76:76;e1-10. 


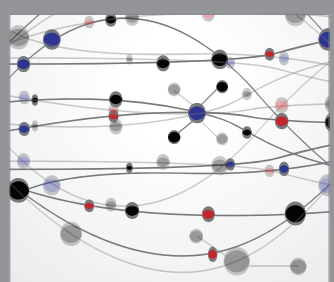

The Scientific World Journal
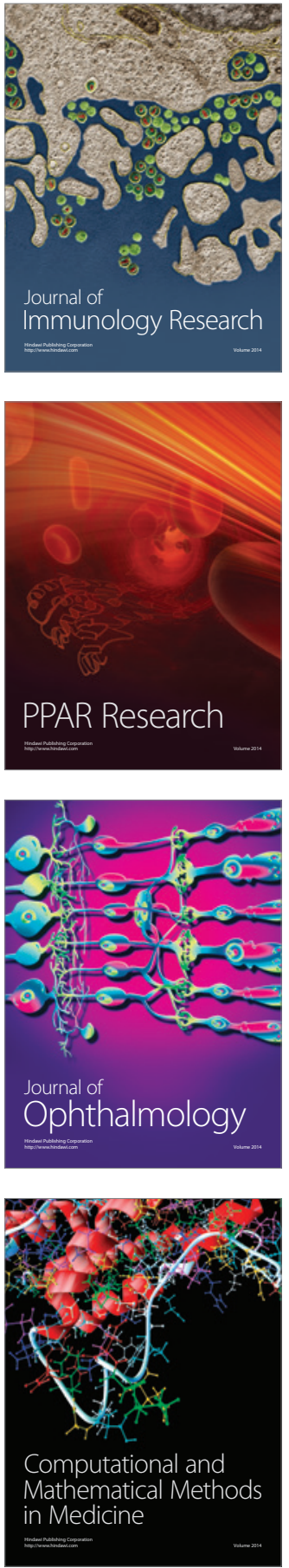

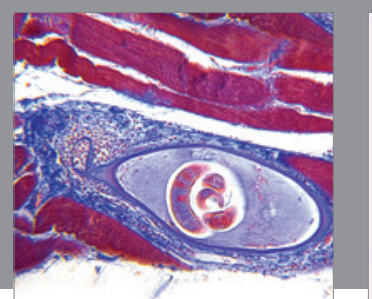

Gastroenterology Research and Practice

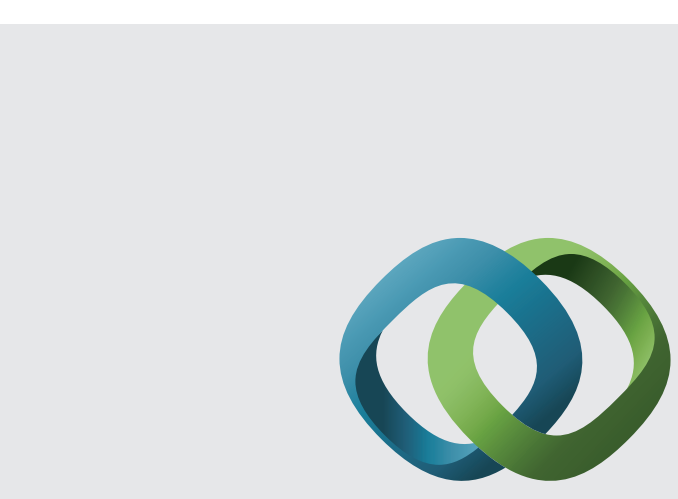

\section{Hindawi}

Submit your manuscripts at

http://www.hindawi.com
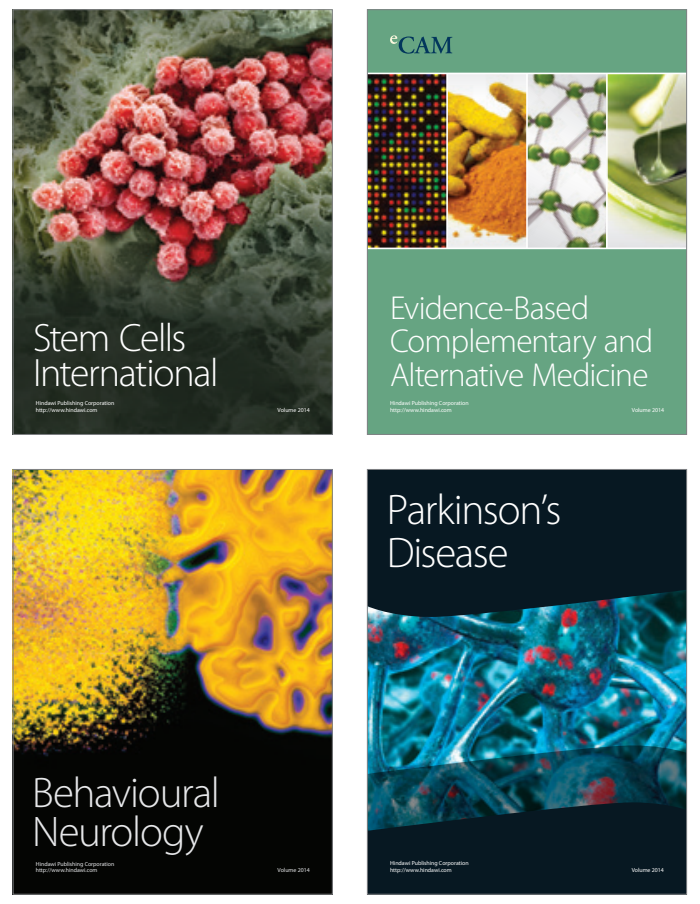
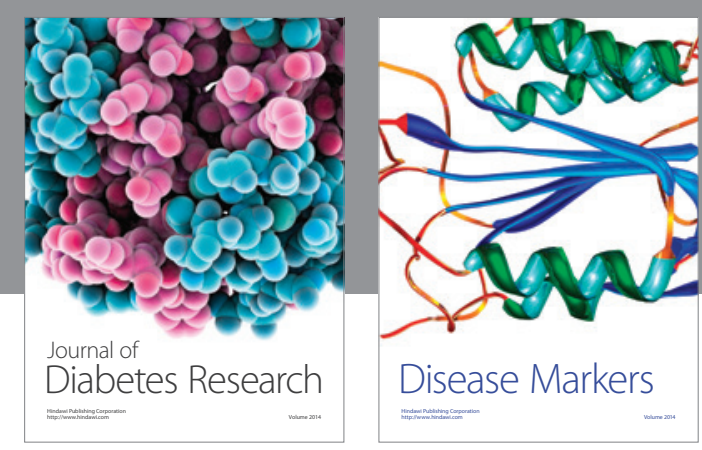

Disease Markers
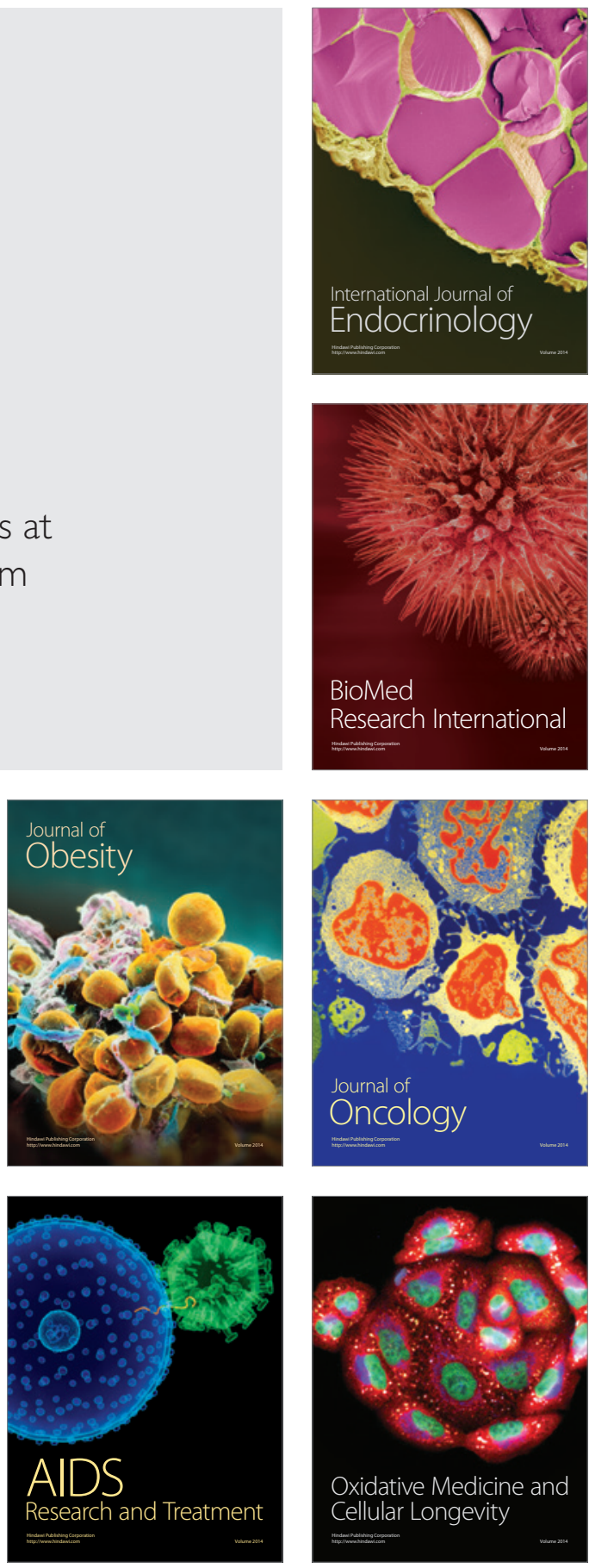